\title{
Understanding Waste Rock Dump Hydrology is Essential for Effective Closure Planning and ARD Management
}

\author{
A. Wright Metago Environmental Engineers, Australia
}

\section{INTRODUCTION}

The creation of large unsightly waste rock dumps is synonymous with mining in much of Western Australia (WA). In many cases development of the dumps has involved only limited consideration of future closure requirements and at best has been based on known technologies of the day. The key design focus has generally been haulage cost. Now, many years later, we are faced with far more stringent decommissioning requirements and ever increasing public interest in environmental sustainability. To complicate matters, what in many cases were "ugly, but harmless mountains of mine rubble", now appear to be "contaminant time bombs". Seepage and runoff from the dumps are often found to have raised concentrations of salts and metals resulting in potential contamination of what might be considered pristine surface and ground water environments. The true magnitude of the problem remains unknown, but there is little doubt that at many mines it represents a potential nightmare for mine closure planners who need to minimise long term corporate liability.

Too often little, if any, consideration is given to waste rock dump hydrology during mine planning stages with the result that there is limited knowledge regarding possible seepage/runoff pathways once acid rock drainage (ARD) occurs. There is little doubt that an adequate understanding of waste rock dump hydrology is essential in the development of any Source-Pathway-Receptor model. Formulating effective long term solutions is extremely risky if the pathway component is not fully understood - in this case the inner waste rock dump hydrological processes.

This paper describes how gaining an insight into waste rock dump hydrology at a mine in northern WA has greatly enhanced closure planning by highlighting some of the impracticalities of earlier closure strategies. The paper discusses internal dump structure, hydrological flow paths, discharge hydrographs and water quality implications.

\section{STUDY SITE}

Mining at the study site began in the mid 1980s and by early 2005 had generated more than 700 million tonnes of waste rock material. The resultant waste rock dump now covers an area of some 650 ha of which more than $40 \%$ represents slopes at an angle of repose. The waste dumps were constructed by end tipping, initially along the flanks of natural ridges and later over the natural profile extending across the plains (Figure 1). The waste dumps are located to the immediate north and south of the mine pit and abut against the existing hills. Mining economics have dictated that the waste rock be dumped in a series of terraces so as to minimise haul distances and gradients. In particular where waste stripping is carried out at higher elevations, the tendency has been for waste rock to be dumped along the natural slope in a series of benches. The benches are tied in to lower terraced areas resulting in effective waste rock dump heights of $300 \mathrm{~m}$.

The southern waste dumps, the focus of this study, currently extend over the plain for a distance of $800 \mathrm{~m}$ and are expected to have a final foot print some $1500 \mathrm{~m}$ south of the original ridge. The dumps extend from $500 \mathrm{~m}$ AHD down to $185 \mathrm{~m}$ AHD by means of ten benches of variable width (30-200 m) and height (15-90 $\mathrm{m})$.

Waste material has in the past been placed in the dumps as they developed, resulting in an admixture of material types throughout the dumps. The excavated material consists predominantly of quartzites and shales, exhibiting a wide distribution of particle sizes ranging from large blocky competent quartzite to silt 
size fraction. The identification in recent years of sulphide minerals in several of the waste rock types resulted in selective placement of this adverse material. In addition to waste rock material, ore stockpiles representing wet season supply are located on some of the upper southern terraces.

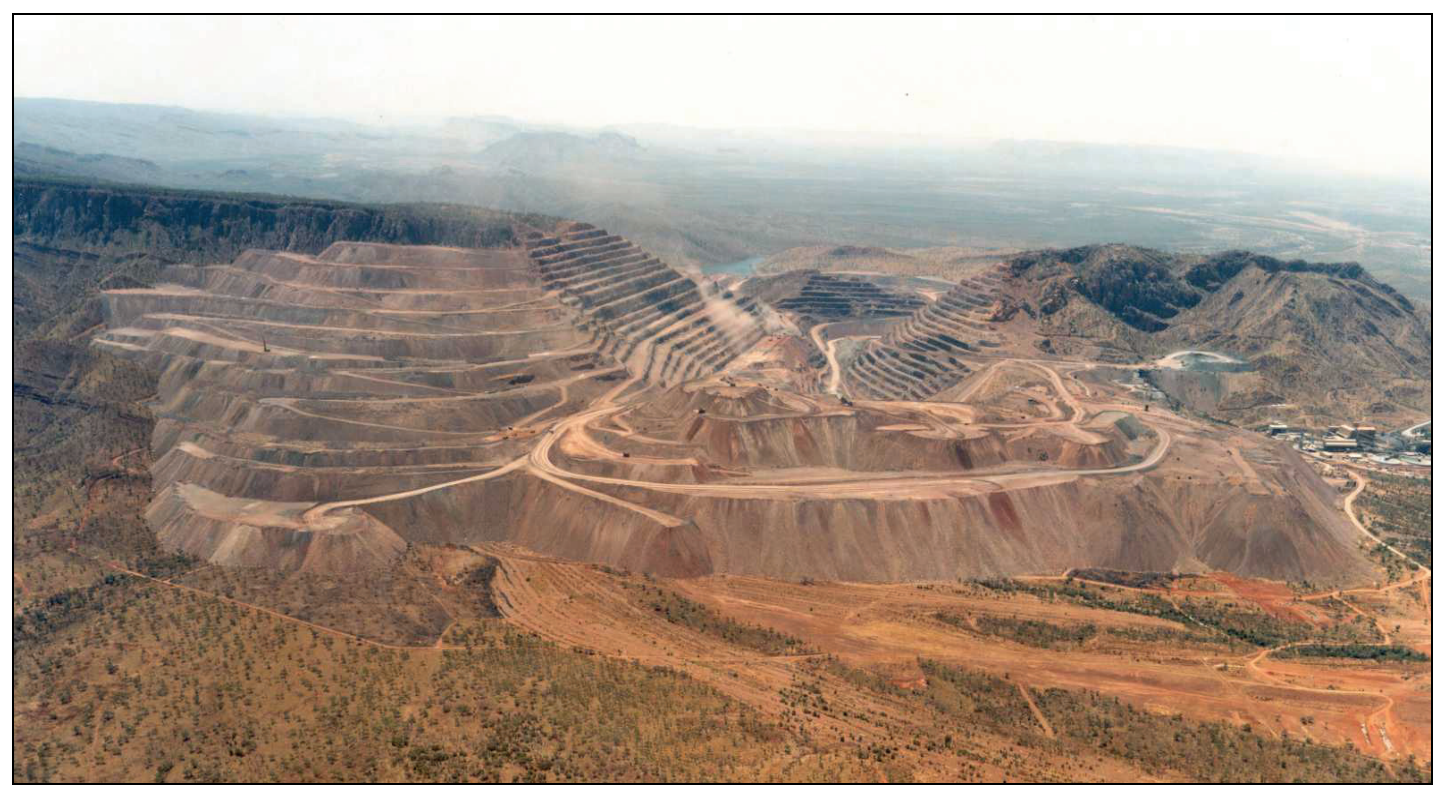

\section{Figure $1 \quad$ Aerial view of the southern waste rock dumps}

Located in the sub-tropical monsoonal north, the mine experiences a warm dry winter and hot wet summer. The wet season extends for 4 to 5 months with an average annual rainfall of some $710 \mathrm{~mm}$, although in wet years it can exceed $1500 \mathrm{~mm}$. Most precipitation is in the form of short intense thunderstorms or cyclonic systems that can have intensities in excess of $75 \mathrm{~mm} / \mathrm{hr}$. Average daily temperatures range from $34^{\circ} \mathrm{C}$ to $42^{\circ} \mathrm{C}$, with the annual evaporation rate exceeding rainfall. During most wet seasons the average monthly rainfall exceeds potential evaporation.

\section{THE ISSUE}

At the end of the 1998/99 wet season white crystalline deposits were observed along the creek bed extending for approximately $17 \mathrm{~km}$ from the foot of the southern waste rock dumps. This had been a season of exceptionally high rainfall with $535 \mathrm{~mm}$ in a single month and $1720 \mathrm{~mm}$ for the year. Sampling of the waste rock dump discharge indicated acid rock drainage with $\mathrm{pH}$ levels of 4.5, sulphate concentrations exceeding $6000 \mathrm{mg} / \mathrm{L}$, magnesium $1400 \mathrm{mg} / \mathrm{L}$ and calcium at $400 \mathrm{mg} / \mathrm{L}$ (Griebel et al., 2005). Subsequent monitoring indicated the occasional presence of heavy metals.

The mine management immediately responded with an ARD management strategy that included:

- Construction of an interception trench and runoff retention dam.

- A waste rock characterisation investigation.

- A hydrological monitoring programme.

Results from this initiative indicated that although only $5 \%$ of the waste rock material by mass was potentially acid forming (Griebel et al., 2005) it would, at the current discharge rate of $5.4 \mathrm{~kg} \mathrm{SO}_{4}$ per kL, continue discharging contaminated water for at least 85 years and more likely centuries. This would be discharging into what is considered a pristine receiving environment (surface water sulphate levels $<5 \mathrm{mg} / \mathrm{L}$ and groundwater $<50 \mathrm{mg} / \mathrm{L}$ ).

Possible closure strategies under consideration include:

- Construction of store and release covers. 
- Chemical treatment of waste rock dumps.

- Capture and chemical treatment of all discharge (Griebel et al., 2005).

Questions however arise about the possible cost and sustainability of these measures over time. In order to answer this it is necessary to take a better look at the waste rock dump hydrology and the "pathway" component of the Source-Pathway-Receptor model.

\section{WASTE DUMP HYDROLOGY}

\subsection{Discharge Hydrographs}

Continuous monitoring of waste rock dump seepage at two sites has shown that the shape of the hydrograph differs between catchments as well as over the duration of the wet season. The south-eastern waste rock dump hydrograph typically has two distinct peaks to the hydrograph (left-hand graph in Figure 2). A steep rising limb ends in a rather sharp peak before rapidly falling away again. This first peak is as a result of overland flow off the very steep waste rock dump slopes and occurs very soon after the rain commences. It also ends soon after cessation of the storm. The second lower peak, some 6 to 12 hours after the first peak, is due to rapid interflow. This rapid interflow condition persists for longer periods and results in the broader peak and more gentle recession curve. With time the flow changes to delayed interflow and the recession curve becomes more concave to finally flatten out completely. It is difficult to identify any distinct groundwater contribution although a degree of shallow subsurface flow must, within certain areas of the catchment, be contributing to base flow. Shallow subsurface flow (below the original ground surface) is in the truest sense delayed interflow and only discharges to the surface in those areas where channels have eroded significantly through the weathered horizon. It is considered unlikely that the deeper groundwater plays any role in the seepage/runoff at the foot of the south-eastern waste rock dumps.

Early Wet Season

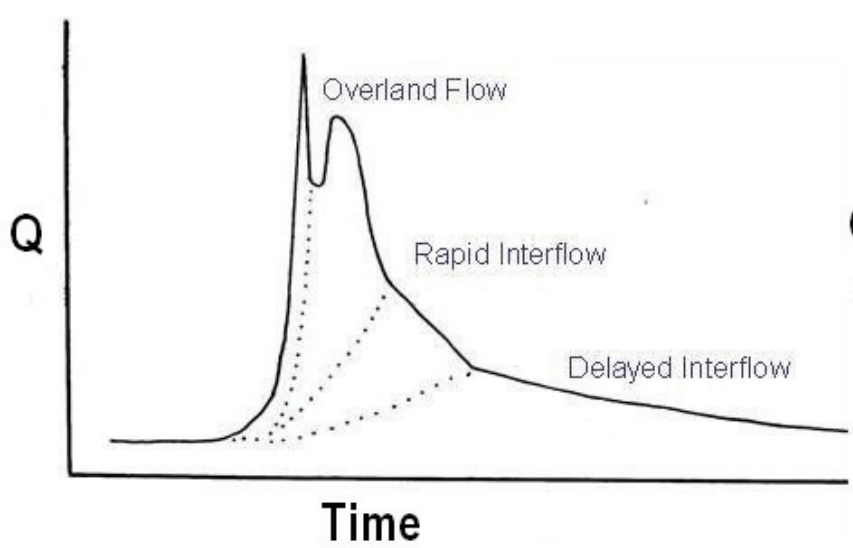

\section{Late Wet Season}

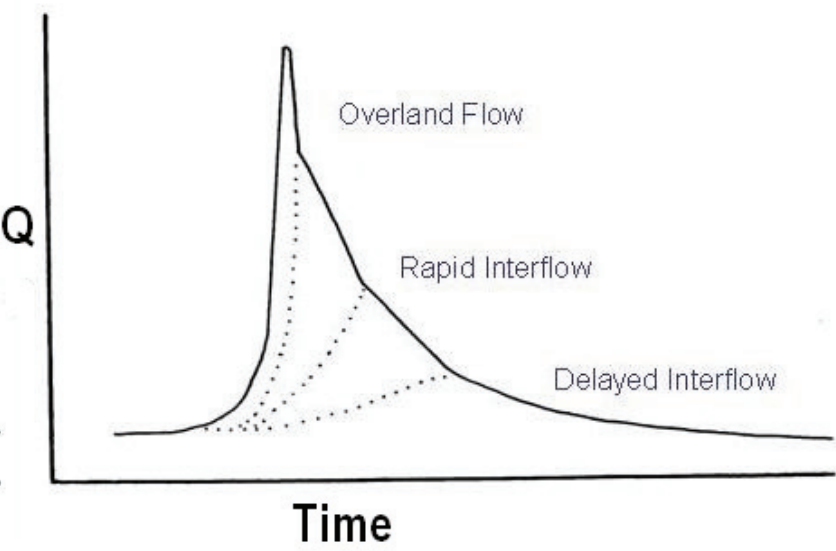

\section{Figure 2 Typical hydrograph for the south-eastern waste rock dump discharge}

By mid wet season sufficient rain has normally fallen to result in a degree of saturation within parts of the waste rock dump. This permits translatory flow (as defined by the Hewlett Runoff Model - Hewlett, 1961) to take place and results in the merging of the twin peaks to give a classic single peak hydrograph (right-hand graph in Figure 2). The translatory flow results in an immediate discharge of interflow at the base of the dump as a direct consequent of infiltration-induced interflow at the top of the dump and little, to no, gap in time between the contribution from overland flow and interflow. Clearly the water discharged at the base of the dumps is not the actual water infiltrated at the top of the dump. The steepness of the rising limb is a direct consequence of the short intense nature of storms and the close proximity of the gauging station to the foot of the dump slopes. The shape of the catchment and original drainage network below Razor Ridge results in flow from the entire area arriving at the single discharge point at roughly the same time. 
The shape of the south-western dump hydrograph (Figure 3) differs from that seen at the south-eastern waste rock dumps (Figure 2). The "twin peak" profile is seldom seen, and if present, is less well defined. The narrowness of the peak suggests that there is very little overland flow and that any rapid interflow arrives at stagged intervals as a result of the rather elongated shape of the sub-catchment. The reduced volumes of overland flow and rapid interflow from the upper dumps is probably largely due to the narrow benches that effectively shed water back down haul roads into the pit. Delayed interflow provides greatly reduced flow volumes, but is present for extended periods resulting in a relatively flat recession limb. A unique feature of the recession curve is the presence of numerous, fairly symmetrical peaks long after the storm event. This 'dragon's back' like recession curve is considered to result from delayed influxes of flow from the upper reaches of the catchment. The source of the interflow is both via the waste rock dump and rapid interflow from within the western ridge. All flow being channelled down a single drainage line below the southwestern waste dumps (Figure 4).

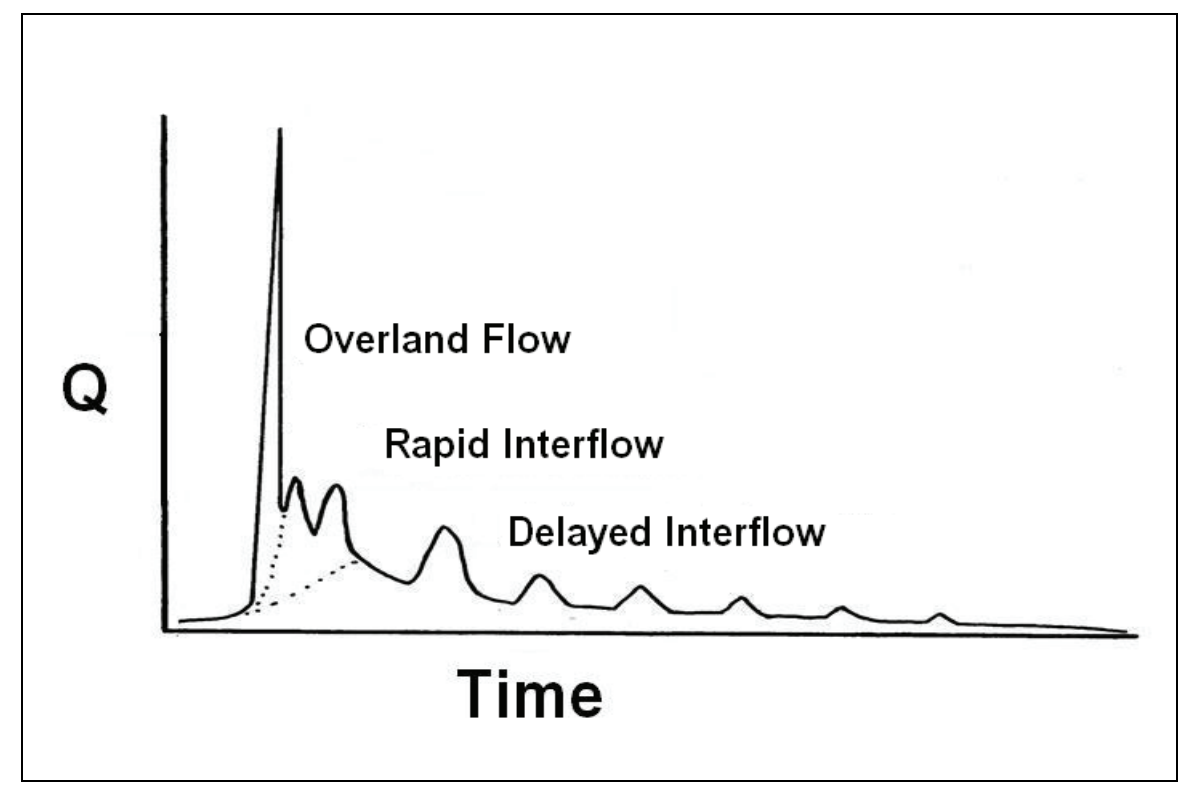

Figure 3 Typical hydrograph for the south-western waste rock dump discharge

\subsection{Discharge Points}

Water discharging at the foot of the southern waste rock dumps was found to be concentrated at only four localities. These sites relate directly to pre-existing drainage lines (Figure 4). Examination of early photographs show a number of steep drainage lines off what was originally known as Razor Ridge. The creeks appear to be deeply incised into the surrounding plain, merging at what is today the outer edge of the waste dumps. The placing of waste rock dumps over these sub-catchments has not changed the fundamental drainage pattern, rather created an overlying, relatively porous "sponge" that temporarily stores any precipitation falling on the catchment. Most water passing through the dumps will naturally continue to flow down gradient to the lowest point in the underlying topography - the pre-existing creeks.

This natural concentration of discharge from more than 245 ha of waste rock dump catchment to a few exit points bodes well for possible discharge management. However, further investigation in those areas displaying no surface discharge indicated significant shallow sub-surface flow. A shallow ( $2 \mathrm{~m}$ deep) 'investigative' trench that extended less than $3 \mathrm{~m}$ below the foot of the dump in an area known to be a topographic and hydrogeological high (the groundwater table is $>20 \mathrm{~m}$ below ground level) intersected considerable seepage water in the upper, highly weathered soil horizon (Figure 5). Minor seepage could still be observed more than 5 months after the last rainfall event. It is this shallow seepage (delayed interflow) 
that is thought responsible for seepage (return flow) observed in creeks located between 200 and $500 \mathrm{~m}$ beyond the waste rock dump footprint.

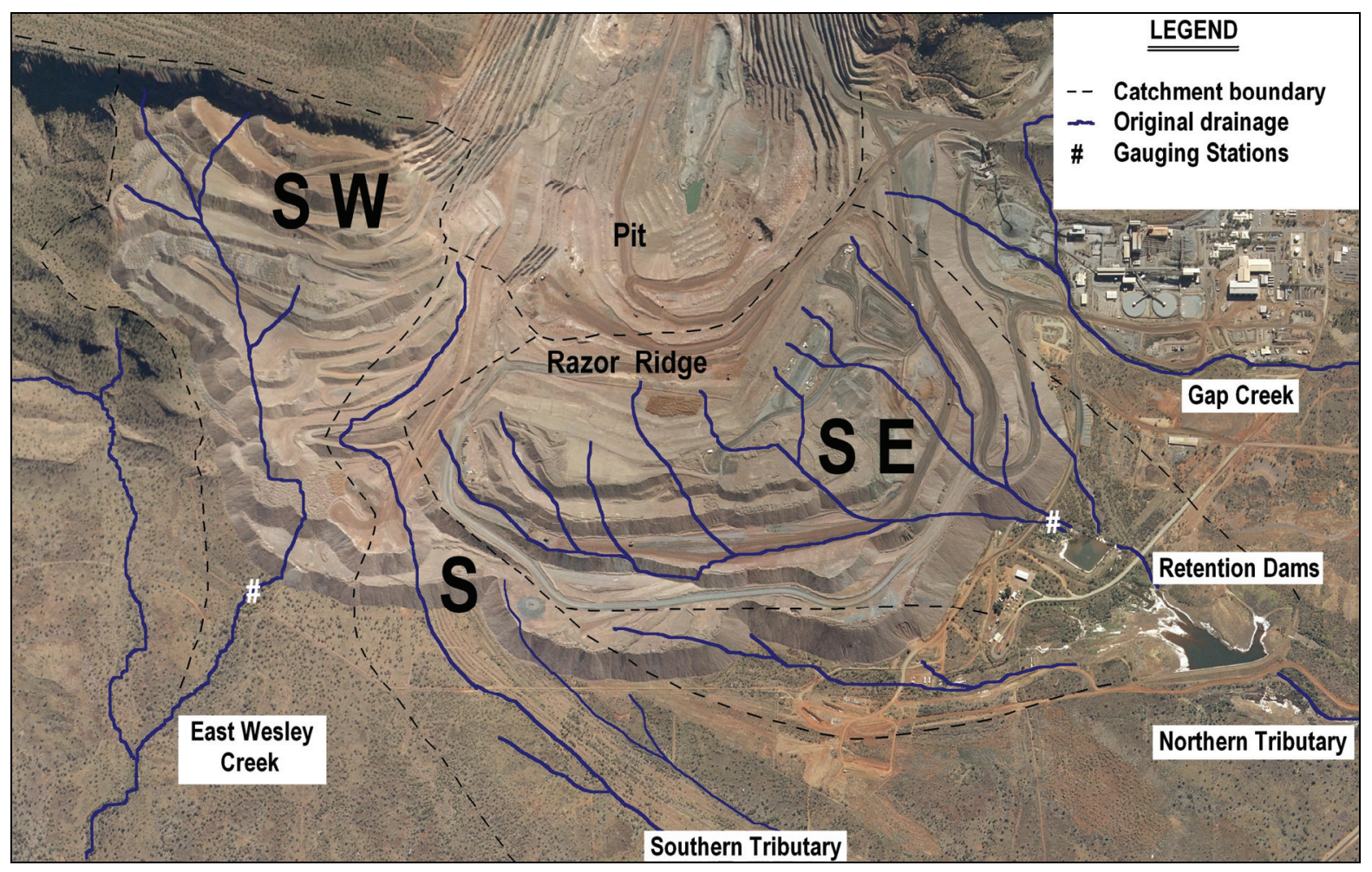

Figure $4 \quad$ Plan showing waste rock dump sub-catchments and pre-mining drainage network

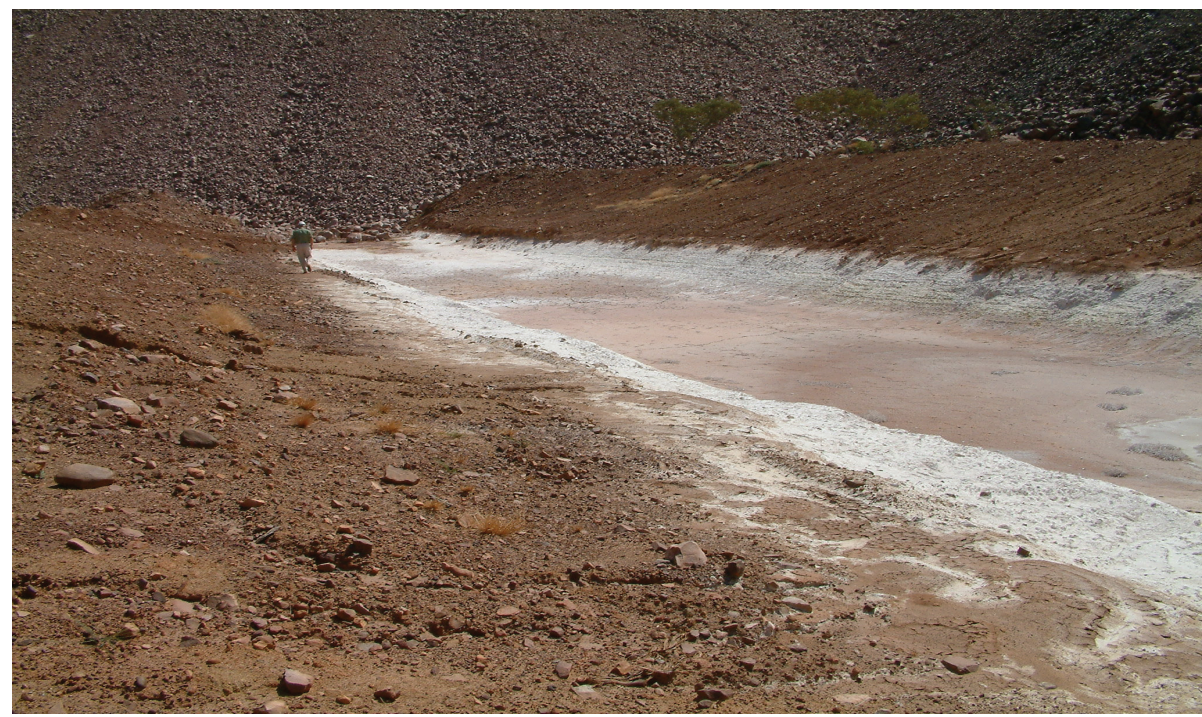

Figure 5 Salts resulting from shallow sub-surface flow beneath a waste rock dump

The local groundwater table is at least $10 \mathrm{~m}$ below ground level and is not thought likely to mound sufficiently during the wet season to contribute to the baseflow component of the hydrograph. Waste dump infiltration is however causing a slow, but steady rise in groundwater levels $(1 \mathrm{~m} / \mathrm{yr})$. Groundwater sulphate 
levels (concentrations) have also been measured at more than 5 times background levels. Fortunately the area has no known fractured rock aquifers and is located within the mine dewatering cone of depression.

\subsection{Dump Structure}

The structure and composition of the waste rock dump determines how water will move through and off the dumps. It also influences the chemical reactions and processes that take place within the dump and hence the resultant water quality discharged from the dumps (Fala et al., 2005).

The southern dumps at the mine have been constructed by end tipping, initially over the edge of the natural escarpment and later off terraces formed as a buttress to the ridge. Each truck load of waste rock tipped distributes the material along a plane at the angle of repose. These planes are significant as they result in distinctive parallel bands of material forming as the miners remove distinct geological units/blocks within the pit. A significant degree of segregation of particles takes place along each plane with the upper reaches of the dump having a much smaller average particle size than the lower portion. This results in a lower zone of coarser material extending across the entire footprint of the dump. This more permeable lower zone contrasts dramatically with the underlying natural ground surface resulting in preferential horizontal flow along the pre-existing land surface. In addition to this, a degree of horizontal compaction can be expected along the upper surfaces of terraces/benches as a result of vehicle movement. Surface compaction due to construction traffic can result in layers of up to $1 \mathrm{~m}$ in thickness (Fala et al., 2005) that can lower the hydraulic conductivity by approximately 1.5 orders of magnitude (O'Kane \& Waters, 2003).

The waste rock placement has a direct bearing on the way water infiltrates through the waste rock dumps. The coarse, blocky nature of much of the waste material (quartzite and sandstone) results in large pore spaces or macro pores, providing enhanced infiltration capacity. This coupled with short, high intensity rainfall ensures rapid infiltration of a large percentage of the rain that falls on the dump. Percolation rates in the underlying coarse material remain high due to preferential flow paths in the blocky, quartzitic material. The general path of movement of water through the waste rock dump is thought to be close to the angle of repose in the upper portion of the dump where particles are significantly finer. As the water particles move further down the amount of fine material decreases and the water takes a more vertical path. The particle velocity will tend to increase along the flow path as a result of the increased permeability. The greater the storm intensity and infiltration rate, the greater the rapid interflow component to the total discharge. Tracer tests done in a North American waste rock dump study by Nichol et al. (2003) showed that rapid interflow can have residence times measured in hours.

Infiltration within the more argillaceous lithological units (bands) is by means of normal unsaturated flow. The wetting front is not however uniform across the dump, but propagates fastest in the finer grained lithologies (Fala et al., 2005). Over time some units may become saturated and any fresh rainfall infiltrating the dump results in a fairly rapid (hours) outflow at the base of the dump as a result of transient flow. This flow combines with the rapid interflow component originating from the coarse units.

Field tests by O'Kane Consultants (Wright, 2005) indicated average saturated hydraulic conductivity of the waste material of:

- $\begin{aligned} & \text { End tipped dumps } \\ & \text { - }\end{aligned} \quad \begin{aligned} & -5 \\ & \text { Paddock dumping }\end{aligned} \quad 1 \times 10^{-2} \mathrm{~cm} / \mathrm{s}$

One-dimensional soil-atmosphere modelling indicates average net percolation rates of $46 \%$ with rates of more than $60 \%$ during wet years. This is similar to net infiltration rates of $55 \%$ to $85 \%$ measured by Nichol et al. (2003) in an uncovered waste rock pile experiencing similar large rainfall events. Flow measurement at the study site confirm that as much as $65 \%$ of total annual rainfall on the waste rock dump catchment exits the dumps as toe seepage/runoff (Wright, 2005).

\section{CONCEPTUAL MODEL}

Figure 6 illustrates the conceptual hydrological model for the southern waste rock dumps and shows what is considered the primary drainage flow paths. The only water entering the dumps is that received during rainfall events. Very little ponding of water takes place during rain events and overland flow from the dump 
slopes $(40 \%$ of total area) is only significant during the more intense storm events. Surface compaction as a result of traffic is limited and only significant on the narrow upper dumps where haul roads comprise a disproportionate percentage of total surface area. These benches are also sloped to drain inwards towards the mine pit resulting in considerable surface runoff into the pit during rainfall events. Water losses due to evaporation are considered low during the wet season as water appears to rapidly infiltrate below the upper layers of the waste material. The relatively coarse nature of much of the quartzitic waste rock material ensures significant infiltration of any precipitation on the dumps.

Rapid interflow results from infiltration along the escarpment - dump interface and within the coarser, blocky units where large pore spaces and macro pores provide preferential flow paths. Water movement is by means of unsaturated flow. The lower coarse zone perpetuates the rapid flow through the dump and down gradient along the pre-existing drainage network. As the wet season progresses more lithological units become saturated so that in time saturated flow within argillaceous units becomes the dominant flow mechanism providing delayed interflow. If there is a phreatic surface within the lower portion of the dump, the water particles will track parallel to the phreatic surface until it exits the dump as toe seepage. A certain amount of infiltration takes place into the underlying highly weathered granitic bedrock. This shallow subsurface flow is, however, very slow and does not appear to move more than $500 \mathrm{~m}$ beyond the foot of the dump.

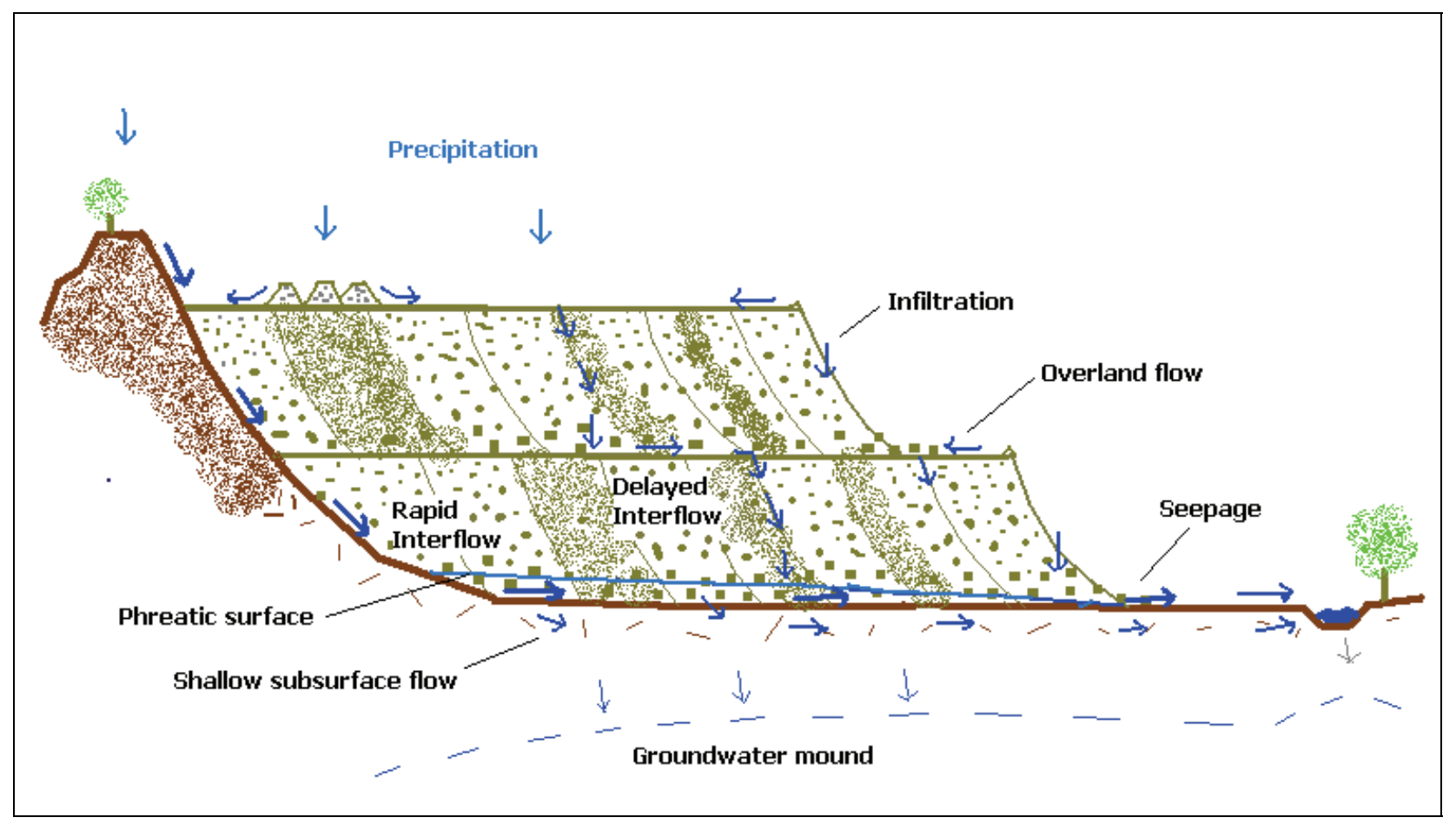

Figure 6 Conceptual model of water flow through the southern waste rock dump

The quality of the water exiting the dump will show both spatial and temporal variation. Spatial variation is due largely to the scatted nature of the sulphidic material (contaminant source material) within the dumps. Temporal variation is in turn due to the accumulation of sulphide oxidation products during the dry season and flushing of these during the wet. Oxidation of sulphide minerals takes place throughout the year due to the readily available supply of oxygen. In this case water is not the main catalyst for chemical reactions, but rather the means for transporting the sulphide oxidation products on a seasonal basis. As the water (effluent) percolates down so mineral dissolution, precipitation, metal mobilization and acid buffering takes place. Since weathering occurs within the rock dump throughout the year, there is an accumulation of the soluble products of weathering within the dump resulting in initial higher than expected salt loads exiting the dump once discharge occurs. With time the loads taper off to represent the actual rate of ARD generation. Figure 7 illustrates the relationship between water quality and flow during a single rainfall event of $80 \mathrm{~mm}$ over 48 
hours. This shows the better quality overland flow component and more saline delayed interflow. Figure 7 has been annotated to show that portion of flow that might be considered acceptable quality to meet receiving water quality standards. In this example almost $60 \%$ of the water discharging during the storm is of an acceptable quality for release to the environment. Typically, provided that adverse material is not exposed on the surface of the dump, the resulting water quality will be worse during the dry season and periods of baseflow. There is the added ability of the receiving environment to, during the wet season, further dilute the discharge water with good quality, natural runoff from within the larger catchment. The same does not happen during the dry season when dilution of the salt load on entering the receiving environment is at a minimum.

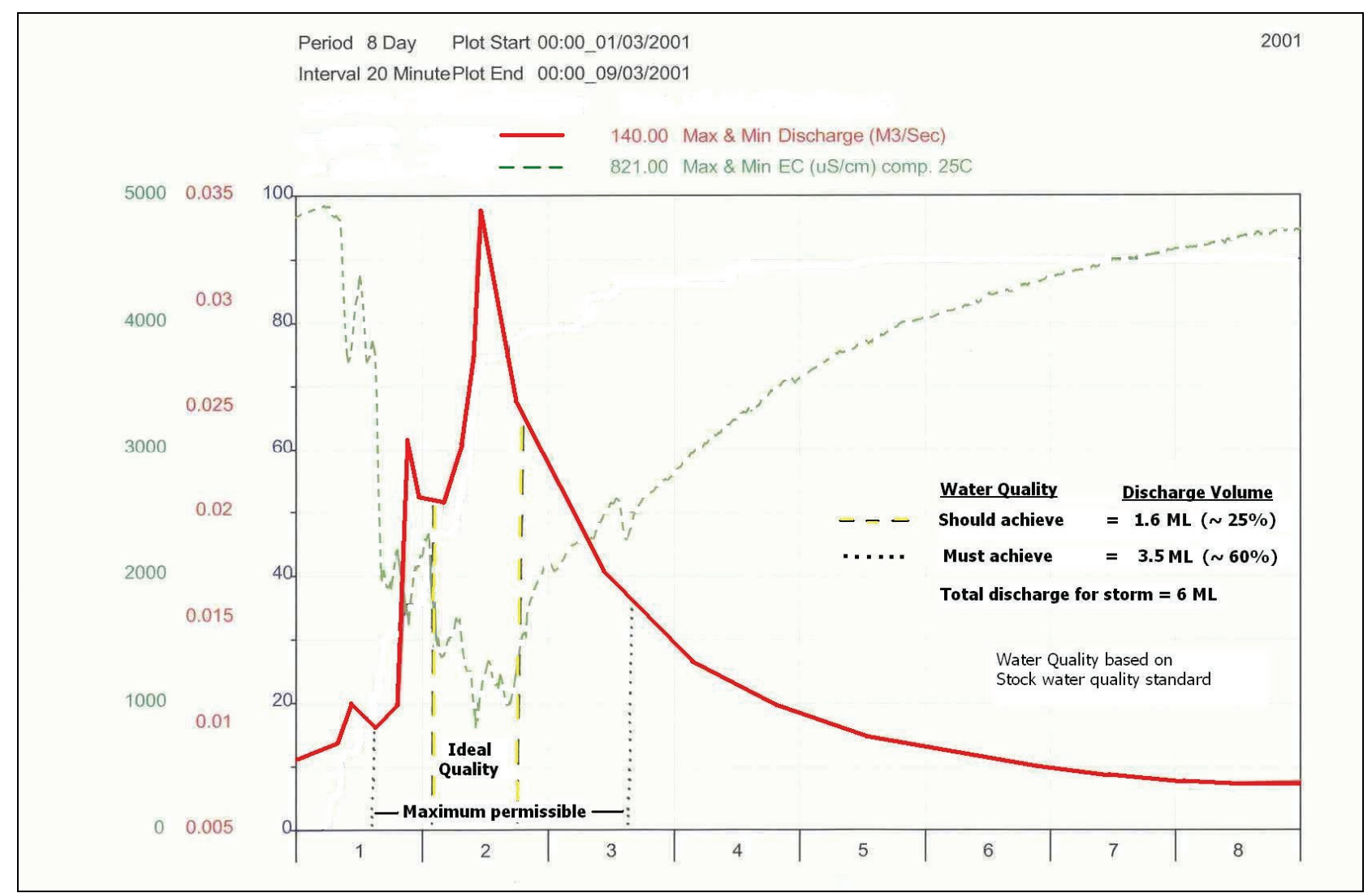

Figure $7 \quad$ Typical storm event hydrograph showing the water quality response

\section{MANAGEMENT SOLUTIONS}

\subsection{Summary of findings}

Information gleaned from the hydrological assessment has a direct bearing on formulation of final closure management strategies. Points of particular relevance are:

- Between 50 and $65 \%$ of annual precipitation falling within the waste rock dump catchment during the brief wet season discharges as seepage/runoff at the toe of the dumps for up to 10 months of the year.

- The composition and structure of the waste rock dumps determines how water moves through the dumps and influences chemical reactions and processes that take place within the dump. The coarse nature of much of the waste material ensures enhanced infiltration and rapid seepage along preferred flow paths. 
- Interflow is the dominant hydrological process causing seepage/runoff discharge at the foot of waste rock dumps. Significant discharge only occurs some six weeks after the first substantial rain event of the wet season, but will persist as baseflow (fed by delayed interflow) for at least 6 months after the last rainfall event of the wet season.

- The stormflow (peak flow) component of the hydrograph contains better quality water with baseflow responsible for the majority of the salt load observed. This variation in water quality over time provides a valuable management opportunity.

- The pre-mining drainage system continues to serve as the main seepage flow path beneath the waste rock dumps and helps to concentrate flow from the waste rock dump catchment.

- Water infiltrates into the underlying shallow groundwater system resulting in an accumulation of salts in the upper highly weathered soil horizon. The subsurface flow does not impact much beyond the waste dump footprint and does not pose any danger to local groundwater aquifers.

\subsection{Management Implications}

The findings of the hydrological assessment have significant implications for some of the existing management initiatives. For example, any management strategy that attempts to retard generation of contamination (e.g. a store and release cover solution) will need to include dump slopes within the cover design. Slopes represent some 260 hectares of dump surface and contribute significantly to interflow rather than overland flow. The cover design also has to take into consideration the very high intensity rainfall events experienced (>1000 mm/yr) and sheer volume of rain received over just 4 months of the year. Initial calculations suggest that in this particular setting even the best store and release cover design based on local materials could only effectively manage $30 \%$ of total annual precipitation during wet years. This might be considered a fairly poor return for what could be a rather expensive post-mining implementation. There is, in addition, the ongoing risk of partial cover malfunction as a result of excessive erosion during extreme rainfall events and even possible exposure of contaminant source material. Store and release covers are probably best suited to those areas known to contain encapsulated pods of sulphidic material, rather than all terraced areas.

The proposed strategy of possibly chemically treating both the dump material and discharge water (treatment option) is questioned in the light of the sheer volume of material and discharge that will need to be treated for decades, if not centuries. The volumes of limestone required to be placed over the dumps to form a buffer zone are not locally available, as may be the case elsewhere in WA. The defuse nature of the contaminant source material within the dumps means that the entire dump surface would need treatment. The option of treating the discharge in turn requires construction of storage facilities to capture up to 3.4 GL over four months and ongoing treatment for decades or centuries. This rather open ended time frame is the key disadvantage of this option.

It is suggested that with our better understanding of the hydrological processes and "pathway" component of the model it might be more realistic to concentrate on:

- Containing the sub-surface flow to the immediate dump area. This could be achieved by installation of a $2.5 \mathrm{~m}$ deep trench within the final ' 500 -yr erosion' bund at the foot of the waste dump. Any subsurface seepage captured would be diluted with the better quality storm runoff from the outer dump slopes prior to slow release to the environment via engineered sub-surface drains strategically located above the southern tributary (Figure 4).

- Separation of poorer quality discharge from that which can be reasonably safely discharged to the environment. This minimizing the volumes of water requiring management and making full use of the assimilative capacity of the larger natural catchment. The main waste rock dump seepage discharge continues to be channelized with an engineered diversion system to separate all baseflow from the stormflow component. The poorer quality baseflow component being retained in a retention basin prior to controlled release into the underground mine workings and the stormflow component released for natural dilution within the larger downstream catchment. During the operational phase of the mine all poor quality water would be pumped to the Process Plant for re-use. 
This closure strategy is considered considerably cheaper, is self sustaining and will over time result in the complete leaching of all contaminant to eliminate any ongoing ARD issue. In other words, it takes care of the unknown "time bomb" factor providing far greater assurance to future generations. The strategy also makes use of the assimilative capacity of the natural environment while meeting national water quality standards.

\section{CONCLUSIONS}

Studies in the Kimberley and Pilbara have shown that significant seepage can be expected from below waste rock dumps in the higher rainfall northern parts of Australia. The amount of seepage and discharge water quality is dependent on numerous factors, including: rainfall intensity; dump structure; and dump composition. These combine to determine the ultimate waste rock dump hydrology and internal water flow paths. Flow through waste rock dumps is far from uniform and often difficult to predict if the structure of the dump and material characteristics are poorly understood.

Waste rock dump hydrology in combination with waste material geochemical characterisation determines seepage/runoff water quality. It is the baseflow component of the seepage discharge that is most likely to have poorer water quality and be of environmental concern if not effectively managed.

There is considerable value in developing an understanding of waste rock dump hydrology early in the planning phase of waste rock dump design. This provides greater insight into what impact the new landform might have on the surrounding environment and future land uses. The conceptual hydrological model for the dump, formulated at the time of design, then needs to be regularly up-dated/refined based on actual hydrological monitoring and measurement data during dump construction. This allows for the timely identification of potentially detrimental environmental implications.

Hydrological monitoring needs to be done correctly to ensure meaningful results. The use of automated continuous monitoring equipment and rising stage samplers is imperative for effective data collection. The hydraulic and water quality aspects can not be studied in isolation of each other.

The possible environmental ramifications of our waste rock dump designs can no longer be left to chance as a result of operational strategies geared to short term production needs. Seepage often only occurs after decommissioning of the waste rock dumps when companies can least afford costly environmental liabilities. Mine closure planners should also never forget that what is environmentally acceptable now is unlikely to be acceptable to future generations.

\section{ACKNOWLEDGEMENTS}

The author would like to thank the hydrographers at Ecowise Environmental for the many hours spent generating hundreds of hydrographs covering five years of continuous field data measurement.

\section{REFERENCES}

Fala, O., Molson, J., Aubertin, M. and Bussiere, B. (2005) Numerical modelling of flow and capillary barrier effects in unsaturated waste rock piles. IMWA Mine Water and the Environment Journal 24(4), pp. 172-185.

Griebel, E., Samaraweera, S. and McPhail, G. (2005) Environmental management of secondary ARD products at a West Australian mine. Proceedings of the ACMER 5th Australian Workshop on Acid Drainage, August 2005 Fremantle, Australia, Paper 15.

Hewlett, J.D. (1961) Watershed management, in USFS Southeast. Forest Expt. Sta. Report, pp. 61-66.

Nichol, C., Smith, L. and Beckie, R. (2003) Water flow in uncovered waste rock - A multi year large lysimeter study. Proceedings of the 6th ICARD Conference, Cairns July 2003, pp. 919-926.

O'Kane, M. and Waters, P. (2003) Dry Cover Trials at Mt Whaleback - A summary of overburden storage area cover system performance. Proceedings of the 6th ICARD Conference, Cairns July 2003, pp. 147-154.

Wright, A. (2005) Hydrology of rock dumps and stockpiles. Australian Centre for Geomechanics Seminar on Creating Cost Effective Rockdumps and Stockpiles, May 2005, Perth, Australia, Section 9. pp. 1-20. 